\title{
JOSEPHUS, JOSEPH AND THE GREEK NOVEL
}

\author{
Tim Whitmarsh
}

\section{Josephus as literature}

The challenge to classicists to read Josephus 'as literature' is an awkward one, because it throws into relief the crooked, appropriative practices we undertake in the name of literary criticism. If Josephus' works are to be seen as 'literature' - a category closely associated with specifically Hellenic literary ideals, in much of the ancient world as well as the modern academy ${ }^{1}$-then we are also avoiding looking at them as documents of early Jewish cultural history or belief. 'Literature' is far from a neutral category.

Josephus would, however, have probably approved, at any rate up to a point. In the proem to the Jewish Archaeology-on which this article will focus - he

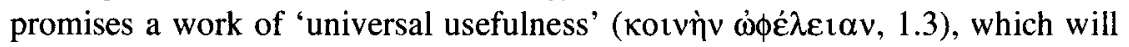

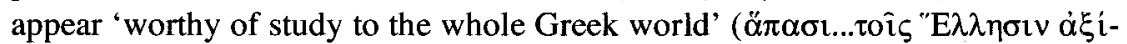
$\left.\alpha v \sigma \pi \circ \delta_{\hat{\eta}} \zeta, 1.5\right)$. Unlike Against Apion, which denigrates Greek historiography in relation to Jewish and other near-eastern narrative traditions (see esp. 1.6-56), the Archaeology seeks to translate biblical discourse into a Greekfriendly register. In terms of communication, 'universal' necessarily means 'Greek', a point of which the translators of the Septuagint were aware (as much as Cicero and Paul). Moreover, the tralatitious language (Thucydidean $\omega \phi \dot{\varepsilon}-$ $\lambda \varepsilon 1 \alpha$, Dionysian $\sigma \pi 0 v \delta \dot{\eta})$ coupled with the direct allusion in the work's title to Dionysius' Roman Archaeology reinforce the already clear impression that Josephus is inscribing his project into the Greek cultural tradition, marking its intelligibility within the conceptual framework that we would call 'literature', and Josephus and his contemporaries called paideia. The Archaeology converts the fragmented and at times self-contradictory narrative of the Hebrew Bible (what Christians call the Old Testament) into a coherent chronological narrative, seeking to confer on it the legitimacy (as gentile Greeks would see it) of historical narrative.

This, however, is a rather defensive characterisation of Josephus' aims in the Archaeology. This text is not just a Hellenicised version of the Bible, but a celebration of the providence $(\pi \rho \operatorname{sov} \alpha),{ }^{2}$ benevolence and justice of the Hebrew god, and of Mosaic law and narrative as a codification of religious propriety (like most ancients, Josephus believes the Torah to be the work of Moses). 'I now call upon those reading these volumes,' orates our narrator, 'to fix their attention $(\gamma \nu \omega \mu \eta)$ on god, to test ( $\delta о \kappa \mu \mu \dot{\alpha} \zeta \varepsilon \imath v)$ whether our lawgiver has divined god's nature correctly, and assigned to him actions coherent with his power' (1.15). In this respect, the Jewish Archaeology stakes a much stronger claim than its model, Dionysius' Roman Archaeology. Certainly, Dionysius has a concept of providence, which (like many of his peers) he links to 
Roman cultural and military superiority. But these ideas are born of a Stoicallyinflected but ultimately conventional historiographical argot (we can find comparable ideas in Polybius); his work is not, as Josephus' is, designed as an expression of the essential truth of a precise and distinctive theology.

There is another reason why Josephus should not be comfortably located 'within' the Greek tradition. This relates to the particular set of genealogical claims embedded in the Archaeology. As everyone knows, much of the Torah is concerned with constructing filial relationships back to the patriarchs, via the seemingly endless lists of 'begats'. Correspondingly, catalogue poetry was essential to Greek cultural self-definition, since at least the Hesiodic Catalogue of Women. Now Josephus carefully-subtly, but pointedly-combines the two traditions, via the figure of Javan ('I $\alpha$ vávos), the son of Noah's son Japheth:

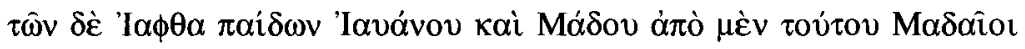

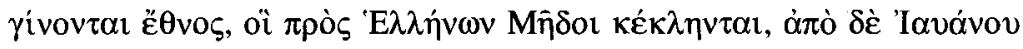

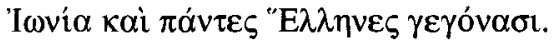

Two other sons of Japheth, Javan and Mados, gave birth, the latter to the Madaeans - the race called by the Greeks Medes - the former to Ionia and all the Greeks.

Greeks played the etymology of Ionia in a number of ways. ${ }^{3}$ This was, however, (so far as we know) the first time that Greek gentile readers would have seen the name etymologically linked to a Hebrew name. Now certainly, the link between Japheth's son and the Ionians does not originate with Josephus. Javan the son of Japheth appears in the fifth-century 'table of nations' at Genesis 10:4-5, a section composed or redacted in the 'exilic' period (i.e. after the deportation of the Jerusalem elite to Babylon of $586 \mathrm{BCE}$ ), and attributed by scholars to $\mathrm{P}$, a priestly author or redactor. ${ }^{4}$ According to $\mathrm{P}$, his sons are 'Elishah, and Tarshish, Kittim, and Rodanim. Of these were the isles of the nations divided in their lands, every one after his tongue, after their families, in their nations' ${ }^{5}$ It is possible that even at this early stage Javan stands as the founder of the Ionians ('Í́Fove $\zeta$ ): 'Kittim' looks like 'the Citians' (from Citium on Cyprus), and Rodanim 'the Rhodians'. In any case, Javan almost certainly represents Greece in the books of the prophets (Isaiah 66:19; Ezekiel 27:13), and does so incontrovertibly by the Hellenistic period (Daniel 8:21, 10:20, 11:2 etc.; also the Dead Sea Scrolls, 4QpNah 2f). It is worth, however, spending a moment comparing Josephus' account of the sons of Japheth to the corresponding passage in Genesis. The Biblical hypotext seemingly represents the Greek world as distantly glimpsed through a relatively early, north-west Semitic lens (hence the dominance of the semi-Phoenician colony Cyprus, which may also explain Elishah). ${ }^{6}$ Josephus' account, however, pares away Javan's troublesome sons, transforming him into the sole progenitor of the 'Ionians and all the 


\section{TIM WHITMARSH}

Greeks'. Beyond updating his biblical prototype, simplifying the connection between Hebrew and Greek genealogy, this has the further effect of provocatively locating the 'original' Greeks not on the mainland but in the cultural creole of Asia Minor. This, of course, is the opposite of the standard Greek cultural myth, which presents Ionian Greece as an excrescence from the mainland. For Josephus, Helicon certainly faced East. There is another provocation to be noted in Josephus' 'table of nations', in that it insistently tabulates the Greeks and the Medes as brethren: the Persian Wars, so central to Greek selfdefinition, become a sibling quarrel down at the end of one of the branches of the family tree of nations. Greek ethnic genealogy, then, is slotted into a larger macrostructure of Hebrew ancestral genealogy. Analogously, the Hebrew patri-

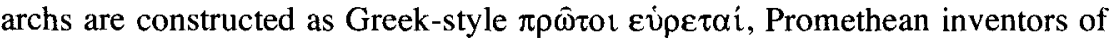
the arts. The Greek narratives claiming cultural origination, of which Josephus was well aware (as Against Apion 1.6-27 testifies), ${ }^{7}$ are trumped by Hebrew narratives of greater antiquity; Jewish culture 'outpasts' Greek. ${ }^{8}$

These two issues - the theological emphasis upon providence and the focus upon the ethnic and cultural priority of the Hebrews-problematise any project to read Josephus 'as literature'. To seek to incorporate him within a Greek frame of reference would be to underestimate the boldness of the task he sets himself: his aim is to demonstrate not the compatibility of Jewish theology with a Greek cultural template, but the primacy and supremacy of Hebrew culture (a project that would be taken up with enthusiasm by Greco-Christians like Clement and Hippolytus). This in fact brings his project, prima facie surprisingly, back into the fold of Dionysian archaeology: but where Dionysius aimed to show that Rome was originally a Greek city, Josephus aims to showdiscreetly - that Greek culture is primordially Hebrew. Josephus' strategy at the genealogical and cultural level, indeed, can be compared to that of Herennius Philo of Byblos, who implicitly aims to root Hesiodic theogony in a supposedly prior, Phoenician tradition. Both authors seek to challenge Greece's claims to cultural originality by demonstrating that a primeval myth-historical expanse yawns beyond the limited horizon of the Greek cultural tradition.

For these reasons, we should be wary of any attempt to read Josephus as literature, to locate him comfortably within a classicist's traditional horizon of expectations. Perhaps the reverse is true: that Josephus encourages us to read literature as Josephan - which is to say, as mediating between a near-eastern heritage of great antiquity and a contemporary Greek readership.

\section{Josephus and Joseph}

My subject here is the Joseph narrative, and more narrowly the scholarly industry devoted to locating it within a Greek literary genre, that of the ideal romance. The Joseph story, indeed, is arguably 'romantic' in its first extant inception, in the Torah itself. The Joseph story occupying the final section of Gen- 
esis (37-50) is very familiar, but it is perhaps, in this godless age, worth reminding ourseives of the setting. Joseph's father Jacob is the first of the descendants of Abraham to settle in Canaan, and thus has a particular relationship with the Hebrew mythology of land occupation. Jacob, alternatively known as Israel, is also the begetter of the eponyms of the 12 tribes of Israel. According to Jacob's blessing at Gen. 49 , the twelve tribes correspond to his twelve sons; 9 but the alternative and more familiar tradition is represented by Gen. 48, where Jacob adopts Joseph's sons Manasseh and Ephraim in place of Levi (the wandering Levites are associated with the portable Ark of the Covenant, rather than any geographical space) and Joseph himself.

The biblical Joseph story is thus pretty anomalous in terms of the patriarchal narrative: why is so much space devoted to the one Jacobite son who has no tribe named after him? Biblical scholars have seen the elements of the Joseph story, which are interwoven with the supposedly older patriarchal narrative of Jacob and his sons, as a post-exilic addition designed to serve two functions. The first is to glue the patriarchal narrative to the Exodus story, i.e. to provide an aetiology for the Israelite presence in Egypt. The second hypothesis is subtler: this is the theory that the narrative of Joseph's success in the Pharaonic court acts as an ideological allegory legitimising the diaspora Jews who were making good in the Babylonian court.

There are indeed good reasons to think that the Joseph narrative, with its sophisticated emphasis upon intrafamilial psychology and the workings of the dreaming mind, is relatively late in date. ${ }^{10}$ There are, additionally, linguistic features found in the surrounding episodes that are missing here. ${ }^{11}$ For further evidence of the lateness of the Joseph story, we could also cite the apparent lack of Josephan Nachwirkung: Not only does Joseph lack a tribe of his own (at least in the overwhelming majority of traditions), but also he is only minimally discussed elsewhere in the Tanakh, and indeed in the Christian bible too. ${ }^{12}$

Another distinctive feature that has been picked up is the emphasis upon Joseph's wisdom and self-control (seen in his sagacious oneirocriticism, his resistance to Potiphar's wife, and his prudent management of both Potiphar's household and, later, of Egypt's economy). Confident in his faith and scrupulous self-discipline, Joseph endures his tribulations and eventually triumphs over adversity (this is a point to which we shall return). This emphasis upon Joseph's intelligence and foresight redeemed looks like wisdom literature transfigured into narrative - another rare feature in the Torah. For these reasons, scholars have often seen the Joseph narrative as an originally independent 'novella' - a Diasporanovelle, ${ }^{13}$ comparable up to a point with the later, Hellenistic, Esther, Tobit and Daniel 1-6-and woven late into the Genesis narrative by a redactor concerned to bind the patriarchal to the Mosaic narrative, but rather less concerned with consistency of tone and content.

It is, however, in the post-biblical phase that the Joseph romance becomes (or is held to have become) novelistic in the Greco-Roman sense. This was first observed by Martin Braun, a Heidelberg graduate who left Germany for Oxford 


\section{TIM WHITMARSH}

in the 1930s. His two ground-breaking monographs, however, have been much more influential in early Jewish studies than in classics. ${ }^{14}$ Braun demonstrated two things. The first was that the Hellenistic period saw a number of fictionalising Greek works built around mainly non-Greek figures of quasi-historical national memory (the Assyrian Ninus and the Babylonian Semiramis, the Jewish Moses, or on the Egyptian side the Pharaoh Sesonchosis and an Alexander now equipped with Pharaonic heritage). The second was that Hellenised Jews, among whom a prime example is Josephus, tend to emphasise the erotic elements of the narratives of the Hebrew Bible, and drape them with Greek novelistic motifs. Braun had a particular interest in the Joseph story, arguing that the apocryphal Testament of Joseph and the epitomised version in the Testament of Reuben (both second century BCE) show the influence of the Greek novel. ${ }^{15}$ The Potiphar's wife episode occupies the first half (1-9) of the Testament of Joseph, demonstrating Joseph's $\sigma \omega \phi \rho o \sigma i v \eta$ in the face of temptation, with allusions not only to the Phaedra narrative in Euripides' Hippolytus, but also to the topical repertoire of the ideal Greek romance. ${ }^{16}$ The second half, meanwhile, shows his endurance ( $\dot{0} \pi \mu_{0} v^{\prime}$ ) in the face of the provocation shown him by his brothers and the Egyptians. In both phases, he demonstrates a faith in the providential happy ending despite the pressures of the here-and-now $-\mathrm{a}$ faith that will, for Hellenists, call to mind the narrative tensions of the novel. According to Braun, the Hellenistic period sees the transformation of the biblical Joseph Novelle into a 'cycle of episodes...comprehensible only on the background of Hellenistic-Oriental romances'. ${ }^{17}$ That our extant 'romantic novels' (as opposed, however cautiously, to 'historical novels' such as Artapanus' Moses, the Alexander Romance, and the Sesonchosis fragment) postdate the second-century BCE Testament of Joseph is a problem of which Braun was aware. ${ }^{18}$ His hypothesis of lost Hellenistic predecessors, known to the authors of the Testaments, is something to which we shall return.

The prime example of a Joseph romance, however, is inevitably Joseph and Aseneth, an extraordinary text that takes the template of the Greek novel and weds it to a conversion narrative. At Genesis 41:45 (cf. 46:20), Joseph is said to marry a young Egyptian maiden, the daughter of the narrative's second Potiphar (the priest of On/Heliopolis, that is-not the servant of Pharaoh whose wife has attempted to seduce him). Joseph and Aseneth might be Hellenistic Jewish, ${ }^{19}$ or Christian, perhaps even late-antique. ${ }^{20}$ It is either a translation from the Hebrew, or written in imitation of such translations: it displays the same paratactic style as the biblical apocrypha, based around Hebrew's distinctive vav conversive and reversive constructions (rendered in Greek by the striking repetition of initial $\kappa \alpha$ í). It is also, however, clearly designed for a readership also familiar with the Greek literary repertoire, toying visibly with the conventions of the erotic novel, with righteous motifs substituted for amatory. For example, Aseneth is egregiously beautiful like a goddess (4.2); she is immediately stupified by the sight of Joseph (6.1), grieves when they are separated after their initial meeting (8.8), and weeps in her room that night (10.2). ${ }^{21}$ 
Yet their relationship is built around not erotic obsession but pious reverence of Yahweh.

This brief survey shows us how the organising category of the novel (at times nuanced as Novelle or romance) has allowed scholars to make sense of biblical narrative by reading it generically through Greek lenses, 'as literature'. I have already sounded some warning signals over this kind of technique, which risks ignoring the fundamental tensions between Jewish and Greek narrative categories. Arguably, however, this process began in antiquity itself, in the cultural crucible of the Hellenistic world: if Braun is right, then Hellenistic Jews were already beginning to refashion the Joseph narrative 'as literature', using the form of an established Greek literary genre, i.e. the ideal romance. (Similar claims could be made for the Maccabaean authors.) But is Braun right? Real questions remain over the direction of influence. Is Jewish culture reinventing itself in response to the magnetic traction of the prestigious Greek literary tradition, as he assumes? Or is it that the Greek novel itself is formed under influence from near-eastern narrative texts such as the Joseph story, as another scholarly tradition (stretching back to Pierre-Daniel Huet in the eighteenth century) claims? 22

To pose the question like this enters us into the high-octane cultural politics embraced by figures like Flavius Josephus himself, who demand that we take a stance on the question of the priority of Greek and Jewish culture. The prudent answer is surely that realities are more complex, that intellectual traffic flows bidirectionally in the contact zones between cultures. But this kind of answer, for all its honesty, is ultimately unsatisfying in its generality. To put flesh on the bones, we need to return to the Genesis narrative, to consider what kind of a text it is, and what kind of resources it made available to later interpreters.

\section{The biblical Joseph and his reception}

Genesis 37-50, the Joseph narrative, divides ancient commentators. ${ }^{23}$ While some commentators (e.g. Artapanus, and Philo: see below) emphasise their subject's pragmatic shrewdness in succeeding under foreign domination without sacrificing his principles, a virtue with obvious relevance for Jews in Hellenistic times, other traditions (visible in parts of the Midrash) are troubled by Joseph's apparent bragging to his brothers, and also by his beauty, which they take as a sign of his culpability in the (non-) affair of Potiphar's wife. ${ }^{24}$ At least part of the reason for the negative tradition must be dynastic: his sons Manasseh and Ephraim were toponymically connected to the northern kingdom of Israel (later Samaria), widely denigrated by the southern Yehudaite scribal elite centred in Jerusalem. ${ }^{25}$

We can trace this equivocation clearly in Philo, writing in the first century $\mathrm{BCE}$, and an important predecessor to Josephus in the Judaeo-Hellenising project. ${ }^{26}$ In the Allegorical Interpretation, for example, Joseph is said to have 


\section{TIM WHITMARSH}

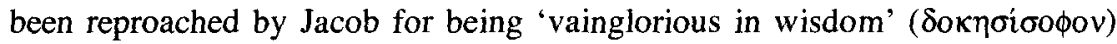
for promising his family sustenance, when true sustenance comes only from the god (3.179-80). In On Dreams, this association with doxa resurfaces, with a Platonic spin: in opposition to the truly wise and self-sufficient Isaac, Joseph 'is

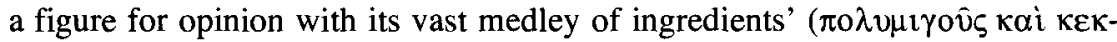

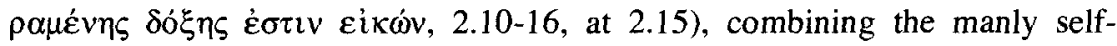
control of his father, Jacob, with the irrational indulgence and sensual pleasure of his mother, Rachel. When Philo proceeds to claim that his 'vainglory' ( $\hat{\eta} \zeta$

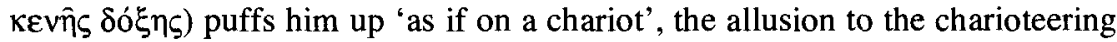
imagery of the Phaedrus traduces the Platonising agenda (2.16). Philo's Joseph represents in general the principle of compromise between the lofty ambitions of Jewish theology and the despicable pragmatism in which it has too often been enmired. In this general context, however, it is a surprise to find that the tract On Joseph is almost entirely laudatory - and, what is more, Joseph is here praised precisely for being an adept statesman ( $\pi 0 \lambda \imath \tau \imath$ kó $\zeta, 1$; cf. the full title,

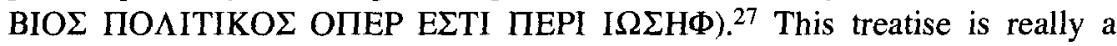
Judaised version of the peri basileias tradition, emphasising the cardinal virtues of the ruler (albeit in a rather non-canonical form). ${ }^{28}$ His political actions are tied not only to Jewish but also to Greek philosophical ideals: thus he is seen as the founder of cosmopolitanism (29-31), and his resistance to Potiphar's wife is seen, here as in the Testament, as an exercise in i $\pi$ ouov

Such surprisingly negative reactions to a major figure in the Patriarchal narrative are, however, not just perverse, post-biblical impositions of anti-Samaritan dogma; or, at least, if there is polemic against the Northern Kingdom, it is already there in the biblical text, where the seeds for a negative appraisal are already sown. ${ }^{29}$ In particular, the early part of the Joseph narrative has some troubling signals: he brings a 'bad report' of his brothers to his father (37.2), and accounts to his family of his dreams (sheaves of wheat bowing down to his sheaf, the sun and the moon and eleven stars bowing down to him) solicit negative reactions not just from the brothers, but also from Jacob himself:

his father rebuked him, and said to him 'What kind of dream is this that you have had? Shall we indeed come, I and your mother and your brothers, and bow to the ground before you?' So his brothers were jealous of him, but his father kept the matter in mind.

(Genesis 37:10-11)

These comments, situated at the very beginning of the biblical Joseph narrative, frame the reader's reception of what follows: Joseph is introduced to us as one whose intimations of preeminence earn his father's scorn. As the narrative proceeds, we reach a series of crisis-points in the moral interpretation. Why does Potiphar's wife find him so attractive? Why does he test his starving brothers for so long? Why does he frame Benjamin for a theft he did not commit, causing great grief to his father? The biblical writer's recessive stance, with- 
holding both appraisal and condemnation, deepens the sense of equivocation. Of all the stories in the Pentateuch, the Joseph narrative is arguably the most complex in its ambivalent portrait, of a key figure in the patriarchal narrative at that. The biblical Joseph thus presents an interpretative challenge. A dominant way of reconciling this complex diversity is to pursue an integrative reading: either encomiastic (as in Philo's On Joseph) or critical (as in Philo's other writings). This will of course involve selectivity and a certain amount of special pleading. What I want to suggest in the remainder of this discussion, however, is that the 'novelistic' approach to the Joseph narrative adopted by Hellenistic Jews represented an alternative, and ultimately more sophisticated, means of negotiating his complex character presentation.

\section{Time for Joseph}

In particular, I shall argue, the element of temporality is what forces the convergence between the Joseph narrative and the Greek novel. By 'temporality' I mean two things: the biblical Joseph narrative is what Ricoeur would call both a 'tale of time', a narrative that rests fundamentally for its effect upon the manipulation of temporal rhythms, and a 'tale about time', exploring it at the thematic level. ${ }^{30}$ Let us begin with the first. The biblical Joseph story is subtle and ingenious in its use of foreshadowing techniques, particularly the narrative 'seed'. ${ }^{31}$ For example in the passage we have just seen (Gen. 37:10), 'Shall we indeed come, I and your mother and your brothers, and bow to the ground before you?', is meant by Jacob as a rhetorical question expecting the answer 'no'. At a deeper level, however the correct answer is 'yes': hierarchies will indeed be reversed, with Joseph occupying a position of political dominance. Perhaps Joseph himself, with his talent for prevision, might be taken already to know this. But in one devastating respect, the narrative tricks him too: Jacob 'and your mother and your brothers' will not, as it turns out, all make it from Canaan to Egypt, since Rachel will die en route (Gen. 48:7).

A more extravagant example of the ironical manipulation of foreshadowing comes in in the prison episode. When Pharaoh's cupbearer narrates his dream, Joseph correctly foresees his release within three days. Then, the narrator continues, "When the chief baker saw that the interpretation was favourable, he said to Joseph, "I aiso had a dream..."' (Gen. 40:16). The chief baker is misled by the assumption that narrative always plays fair, rendering like for like. Unfortunately, his fate is to be hung on a pole, "“and the birds will eat the flesh from you"' (Gen. 40:19). It is left to us to imagine the poor baker's reaction; but the crucial point for the external reader is that this second episode refuses to commit to any pattern, frustrating our expectations. The tantalising difference between the fates of the two pharaonic servants is paradigmatic: it tells us both that Joseph is a better prophet than we, and that there is a mysterious quality to temporality, beyond the ken of mortals like ourselves. 


\section{TIM WHITMARSH}

The Joseph narrator thus knows about narrative foreshadowing, and how to use it. He can also artfully manipulate temporal rhythm: for example, by making the cupbearer forget about Joseph, so that he languishes in prison for three more years (thus emphasising the extent of his suffering, and also the depth of his faith in god); and by delaying Joseph's self-revelation to his brothers, until he has tested them Odysseus-wise (which in fact does risk a Laertes-style neardeath experience for the agonised Jacob). ${ }^{32}$

Another sign of sophistication is the division of the narrative into two episodes, in Canaan and Egypt, carefully patterned around a series of parallels that interlink the episodes by transecting the linear temporality. In the Canaan episode the brothers throw him down into a pit before selling him to the Ishmaelite traders; in Egypt, Potiphar has him thrown into prison. The biblical writer uses the same word meaning 'pit' (bôr or bô' $r, 37: 20-30,40: 15 ; 41: 14$ ) of both. ${ }^{33}$ In both cases, he loses his coat, which is then used as false evidence (the brothers smear his dream-coat with goat's blood, pretending he has been caught by a wild animal; Potiphar's wife uses it as evidence for the supposed rape). Each case, again, is a Scheintod (the association between interment and ritual death is of course common and cross-cultural): he is erased from public memory, although the reader of this narrative knows different. The theme of descent into pits and false death allegorically underscores the larger role of Egypt, as a place of symbolic Scheintod: Joseph's relocation from his homeland (and that of his people) to the great imperial cosmopolis is a virtual death - and in his family's eyes a real one too. ${ }^{34}$ That Egypt is a kind of pit is also figured in the language of journeying to and from: characters 'descend' (yârad, LXX $\kappa \alpha \tau \alpha-$ ) to and 'ascend' ('âlâh, LXX $\alpha$ $v \alpha$-) from Egypt.

So the Joseph story is a tale of time, to revisit Ricoeur's phrase. It is also about time, and in particular about prophecy. Joseph's gift gives him a supernatural command of temporality. His ability to predict the future, as we have already seen, makes him a kind of metanarrator, and intratextual surrogate of the extratextual narrator who commands the unfurling of the plot. This metanarrative capability is also seen in the episode where he repeatedly tests his brothers: his new-found political authority gives him the power to delay the revelation for what seems an uncomfortably long period. In terms of the realist narrative, however, his most important act of far-seeing is his implementation of the grain-storage policy, which sees Egypt (and indeed Canaan) through the seven years of famine. This ability to plan for the future is presented as an economic revolution for the Egyptians, thus reemphasising Joseph's wisdom even in the adoring eyes of a foreign people (a key Diasporanovelle motif, of course).

There is a more subterranean, metaphorical element to this emphasis upon grain and storage. The structural relationship between Canaan and Egypt works at many levels; it is clearest, however, at the level of economy and foodproduction. Canaan is at this time a pastoral economy populated by newly arrived nomads; Egypt, on the other hand, is an ancient, settled economy, funda- 
mentally dependent upon the arable cultivation of the Nile delta. The Israelites do of course know of agriculture ('Abel was a keeper of sheep, and Cain a tiller of the ground', Gen. 4:2), which explains why Joseph can dream of a wheatsheaf at the beginning of the story; even so, within the confines of the Joseph story they are never presented as cultivating the soil. They are 'shepherds, men

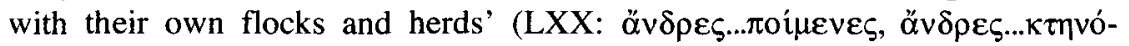
$\tau$ гофor, 46.32). When Jacob sends gifts for the powerful prefect of Egypt (whom no-one has yet recognised as his son), he sends honey, incense, myrrh, terebinth and nuts: all products of the land, but none cultivated (Gen. 43.11). Conversely, the Egyptians are said to find the pasturing of sheep abhorrent (46.34). The Joseph story also works, then, as an aetiology for the Israelites' move from nomadism to settled habitation, supported by the mixed economy of pastoral and arable farming. This may explain the apparent redundancy of Pharaoh's famous twin dream, where the famished cows eat the healthy cows and the withered corn eats the healthy: the same message is 'twin-tracked', using both the pastoralist and agrarian modes. This ideal of settled habitation is implicitly linked to the future return to Canaan, where Jacob insists on being buried, even after the relocation to Goshen in Egypt; after all, the entire Joseph episode begins with the assertion that Jacob was the first to settle Canaan.

This narrative of acculturation also has a temporal dimension to it, since Joseph's achievement is in effect a triumph over the natural seasons: the storage of grain releases humans from their bondage to the annual cycles of abundance followed by hardship, cycles the significance of which is exacerbated by the famine. Agriculture is, moreover, figurative of generational continuity, a connection clearly brought out in the biblical text, where the same word (zera', LXX $\left.\sigma \pi \varepsilon \varepsilon^{\prime} \mu \alpha\right)$ is used both of Jacob's offspring (46:7) and of the grain Joseph stores up (47:19). Joseph's mastery of the natural sphere of production serves as an implicit allegory for the permanence of Abraham's dynasty. The Joseph narrative is thus fundamentally about learning to command time, to glimpse a redemptive future beyond any immediate crises. At one level, this message has obvious local resonances to a diaspora readership, longing for return to the imagined community of Judah. But it also connects at a deeper level: it is about the triumph over adversity, over death even, and the redemption of those whom the god favours. In this respect its message is more universal-hence its appeal to a wider audience, and (I shall argue) its receptiveness to refashioning in the guise of a novel.

\section{Josephus and Joseph}

The biblical Joseph was in one respect not an obvious hero for his firstcentury CE namesake, whose contempt for the Samaritan lands associated with the house of Joseph was as strong as anyone's. ${ }^{35}$ Despite this, the Joseph narrative becomes the centrepiece of book 2 of the Archaeology, stretching from 


\section{TIM WHITMARSH}

chapters 7 to 200 , almost $60 \%$ of the entire book. Josephus invests more heavily in this narrative than any other in the Archaeology. This is, no doubt, in part because he felt a sympathetic bond with his biblical namesake: both suffered for their foresight, ${ }^{36}$ were cast out from their homelands by their kin, and achieved success through politics in a foreign court. ${ }^{37}$ But this cannot be the whole explanation, since these themes are not particularly emphasised in Josephus' account. The episodes that he particularly amplifies are two: Potiphar's wife and the brothers' guilty deliberations over their treatment of Joseph. In raising these particular episodes to prominence, Josephus follows the precedent of the novelising Hellenistic Testament of Joseph, which itself follows a similar bipartite pattern of narrative expansion.

In Josephus, however, the novelistic motifs are developed even more powerfully than in the Testament. Joseph is young and naïve at the outset. His ä $\gamma$ vot $\alpha$ is emphasised $(2.11,2.19)$, a device that simultaneously explains away the offence he causes his brothers through his self-aggrandising dream stories and transforms the narrative as a whole into one of intellectual development: in due course he will become known for his ouvvers (2.80). As we saw, the biblical account of Joseph frontloads all the problematic character description, which provokes hostile readers to evaluate him negatively throughout. Josephus, on the other hand, allows for character development. His early behav-

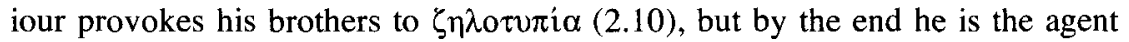
of the resolution of all of this intrafamilial discord. In this respect, Josephus' Joseph looks strikingly close to Chariton's Chaereas. Like Joseph, Chaereas falls prey to the jealousy of others (Callirhoe's other suitors, Char. Call. 1.2.1), and is led by his naivety into a chain of events that separate him from his family; finally, at the conclusion of the narrative, the president deity (Aphrodite) orchestrates a return to his homeland and a family reunion. Similarly, the brothers are by the end much more explicitly reconciled with Joseph than in the Torah. It is possible, if rather unlikely, that Josephus knew Chariton's text (which the current consensus tends to place, by guesstimation, in the mid-first century $\mathrm{CE}$ ); but that is not a necessary conclusion. The central point is that Josephus supplies a solution to the moral-interpretative problem of the biblical text by supplying a novelistic temporal scheme: the folly of youth is supplanted by mature experience, during the narrative rite de passage. ${ }^{38}$

The novelistic elements are, as we might expect, particularly prominent in the Potiphar's wife scene. Josephus introduces the non-biblical idea that her

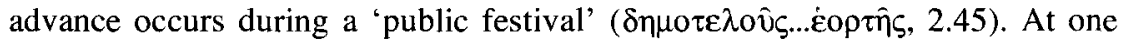
level, this detail is designed perhaps to combat any accusation that Joseph must have been prone to hanging out in the women's quarters: ${ }^{39}$ in the Archaeology, Joseph is initially unaware that Potiphar's wife is even at home. It also, however, introduces a topos of erotic literature from the Greek tradition, namely erotic infatuation at a public festival. ${ }^{40}$ In line with most pre-imperial literature, Josephus presents festal passion as an illicit mode of love. ${ }^{41}$ There is, however, reason to think that he is also familiar with the later, novelised version, which 


\section{JOSEPHUS, JOSEPH AND THE GREEK NOVEL}

turns the lovers into young, consenting virgins: this is suggested by the use of

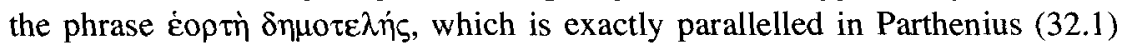

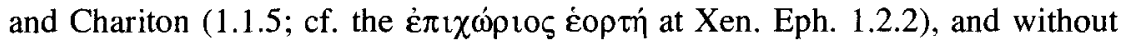
parallel in this kind of scenario in Greek literature preceding the Roman period (where the festival in question tends to be named specifically). ${ }^{42}$ What is more, the reaction of Potiphar's wife to her rejection is seemingly related to Manto's response to Habrocomes' rejection of her in book 2 of Xenophon of Ephesus. ${ }^{43}$ Both are upset by i $\pi \varepsilon \rho \eta \phi \alpha$ vi $\alpha$ (Jos. 2.54; Xen. Eph. 2.5.5); both arrange themselves to look like rape victims, both ask the head of the household for their

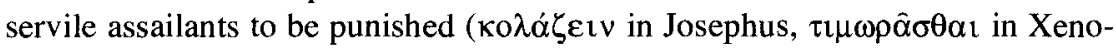
phon) for $\ddot{\beta} \rho \imath \zeta_{\text {; }}$ both accuse the latter of false $\sigma \omega \phi \rho o \sigma i v \eta$; each threatens death, Xenophon's Manto her own, Potiphar's wife her husband's (Jos. 2.5556; Xen. Eph. 2.5.6).

There is of course much more that could be said about the use of novelistic motifs in Josephus' version of the Joseph narrative. Rather than supply a list of correspondences (much of which would retread ground already covered), ${ }^{44} \mathrm{I}$ want to return to idea of the manipulation of temporality. As we saw earlier, the Joseph story in Genesis is notable for its sophisticated treatment of timeappropriately enough in the case of the Tanakh's first prophet. Josephus' Joseph is equally prophetic, but in a way that suggests the complex approach to prolepsis characteristic of erotic romance ${ }^{45}$ rather than an allegory for the Hebrew god's care for his people and land. When imprisoned, Joseph is capable of bearing his present sufferings manfully, confident that the providential power of God will redeem him in the end:

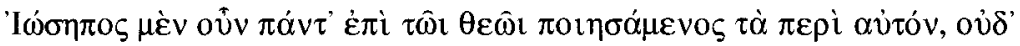

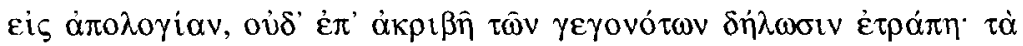

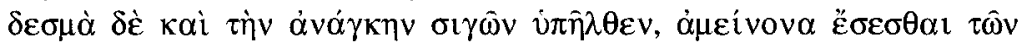

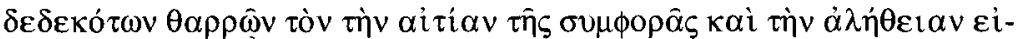
$\delta o ́ \tau \alpha \theta \varepsilon$ óv.

Joseph on his side, committing his cause entirely to God, sought neither to defend himself nor yet to render a strict account of what had happened, but silently underwent his bonds and confinement, confident that God, who knew the cause of his calamity and the truth, would prove stronger than those who had bound him; and of his providence he had proof forthwith.

Joseph's grasp of the temporal dynamics of this providential narrative contrasts him with his fellow prisoner, Pharaoh's cupbearer, who blames god as

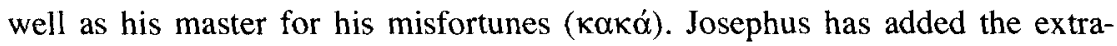
biblical detail that the two are bound together by a single shackle, as though to emphasise their complementary doubleness. If Joseph represents the providen- 
tial reader, then the cupbearer's immersion in his immediate sufferings mark him as one who wallows in the present, without expectation of future improvement. Similarly, at 2.105-07, Joseph's brothers weep continually at their present troubles, while Reuben by contrast seeks to get them to think both in terms of divine providence and in terms of human pragmatism, i.e. about what they can do in the future.

This polarity between two different modes of dealing with time, melancholy immersion and positive thinking about the future, is one of the hallmarks of the novel. I take but one example, again from Xenophon of Ephesus. Towards the beginning of Anthia and Habrocomes, supposedly the most theoretically maladroit of the novels, the fathers of the two lovers, at a loss to explain their children's pining, consult the oracle of Apollo at Colophon. The response suggests to them that they should marry the children, and then send them abroad on a journey. The beginning of that journey marks the beginning of the liminal phase. The two sets of parents react differently to the departure, and to the oracle that motivated it:

Now Lycomedes and Themisto [Habrocomes' parents], recalling every-

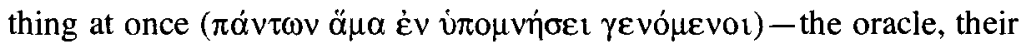
son, the period abroad-threw themselves to the ground despairing ( $\dot{\alpha} \theta v \mu$ ovv $\tau \varepsilon \varsigma$ ). Megamedes and Euippe [Anthia's parents], on the other hand, while they experienced the same emotions, felt more cheerful ( $\varepsilon \dot{v}-$ $\theta \cup \mu$ ó $\tau \varepsilon \rho o \imath$ ), since they looked to the outcomes ( $\tau \dot{\alpha} \tau \varepsilon \dot{\lambda} \eta$ ) of the prophecy.

(Xen. Eph. 1.10.7)

As in Josephus this passage dramatises two different modes of narrative reading. ${ }^{46}$ The first set of parents, like Pharaoh's cupbearer and Joseph's brothers, interpret the present situation as hopeless, based upon their memories of past events. Contrasted with this present-focused reading strategy is the response of the other parents, who (like Joseph himself) take stock not only of the present misfortunes but also of the likely final outcome: 'after their sufferings, they have a better fate ( $\dot{\alpha} \rho \varepsilon i o v \alpha \pi$ ó $\tau \mu o v)$ ', according to the oracle, the voice of narrative authority (1.6.2). The two groups of interpreters are further contrasted in terms of their emotional reactions: the Greek words translated as 'despairing' $(\dot{\alpha} \theta v \mu o v v \tau \varepsilon \varsigma)$ and 'more cheerful' ( $\varepsilon \dot{\theta} \theta u \mu$ ó $\varepsilon \rho o \imath)$ are both rooted in thumos, which denotes vigorous energy. Thumos stands for a hermeneutic energy, the desire to read on. The experience of novelistic narrative, this passage teaches us, involves balancing affective absorption in the immediate crises with a more detached awareness that we are reading a generic work that promises a more positive destination. 


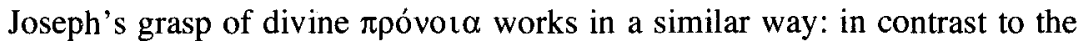
theologically disadvantaged Egyptians and his morally reprobate brothers, he extricates himself from present circumstances and reads for the divine plot: he becomes the living embodiment of the ideal reader Josephus craves from the start, one who will test the narrative as proof of Yahweh's providence. Providence is, as Attridge and others have emphasised, a central theme for Josephus. ${ }^{47}$ But it would be a mistake to see this simply as a token of his pious Yahwism. Providential themes recur throughout imperial Greek literature, not least in the Greek novel, where it becomes a sophisticated metanarrative device. ${ }^{48}$ What is more, the theme is especially appropriate to the narrative of Joseph, the Bible's most celebrated dream-prophet. In this light, it is especially interesting that we find a close parallel between Joseph's words to Pharaoh and Clitophon's reflections on dreaming at the start of Achilles Tatius:

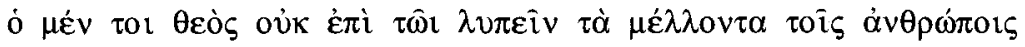

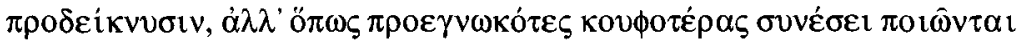
$\tau \dot{\alpha} \varsigma \pi \varepsilon \dot{i} \rho \varsigma_{\varsigma} \tau \hat{\omega} \nu \kappa \alpha \tau \eta \gamma \gamma \varepsilon \lambda \mu \alpha \dot{\alpha} \tau \omega$.

It is not to distress men that God foreshows to them that which is to come, but that forewarned they may use their sagacity to alleviate the trials announced when they befall.

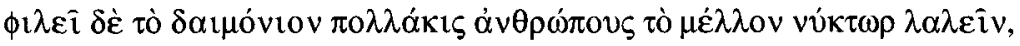

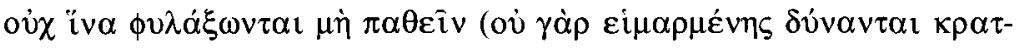

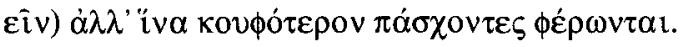

(Ach. Tat. 1.3.2)

The gods often like to reveal the future to mortals at night, not so that we might deliver ourselves from suffering (for destiny is insuperable), but so that we might endure such suffering more easily.

That prediction allows humans to manage future discomfort better is a relatively common sentiment in Greek thought, ${ }^{49}$ but Josephus' phrasing (n.b. the

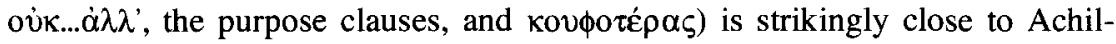
les'. There is, however, a major problem here, which brings into focus all of the issues we have discussed so far. Can Josephus have read Achilles Tatius? Unlikely, at first sight. A scholarly consensus puts him in the second century, from the latter part of which our earliest papyri date. At a stretch he could, in fact, be pushed back to the first century: the second-century date is based only on Achilles' (erratic and inconsistent) Atticism and an ill-defined sense that he is more 'sophistic' than Chariton and Xenophon (whose dates are also uncertain!). But the real issue is not one of dating, since common phrasing can always be explained through hypothetically shared Hellenistic sources. Much 


\section{TIM WHITMARSH}

more important is the question of cultural priority, with which we began. Does the Greek novel begin with now-lost Hellenistic prototypes, which then in turn influenced Hellenised Jews like the authors of the Testament of Joseph and Joseph and Aseneth, and Philo and Josephus? Or did the novel itself emerge from precisely the kind of cultural friction generated by the Hellenising of neareastern literatures?

There will probably never be convincing answers to these questions, for at least two reasons: not only because, as we have seen, matters of dating are so fraught in the study of the novel, but also because (as the last forty years of scholarship on the novel have taught us) the quest after a primordial novel is a hopelessly naive one. Yet there is something profoundly dissatisfying about the current orthodoxy on the novel, which tends to contextualise it within the Hellenising revival of the 'Second Sophistic'. This view springs from Erwin Rohde's labours in the late nineteenth century: it was he who revived the Philostratean phrase $\dot{\eta} \delta \varepsilon v \tau \varepsilon \dot{\rho} \alpha \sigma o \phi \iota \sigma \tau \iota \kappa \dot{\eta}$, expanded its remit to include the novel, and linked it unbreakably with cultural Hellenism. ${ }^{50}$ Rohde's attempt to find Greek origins and a Hellenocentric context for the novel was an implicit rebuff directed towards earlier 'orientalists' like Pierre-Daniel Huet, who viewed it as an import from the Near East. ${ }^{51}$ Rohde was also, one must assume, writing in dialogue with his friend and mentor Friedrich Nietzsche, who viewed the Greek Geist as in terminal decline from the late fifth century onwards, until Richard Wagner came along to revive it. Rohde's Der griechische Roman (published when he was a mere 31 years old) is a magnificent achievement, far subtler than much of the fervid nationalism of its day, but still fundamentally shaped by it.

By contrast reading Greco-Jewish texts as 'literature', dialoguing with the dominant (Greek) cultural force of the time, can help us move beyond the kind of naive 'either-or' of the Greek-barbarian polarity. It may be, indeed, that what we call 'the novel' gained its popularity precisely because of its ability to dialogue in this way. Unlike the genres canonised in Hellenistic Alexandria, the novel had no paternal hypotexts, influencing its progeny towards anxiety. Nor was it constrained by formal requirements like metre. Crucially, it was tied to no performance context within the polis: the novel was (probably) composed to be read, and read wherever it could be read. For all these reasons, it had a suppleness and responsiveness, which allowed it to take on both the Hellenocentric guise of (e.g.) Chariton's Chaereas and Callirhoe and the Jewish inflections of the texts we have discovered above. Indeed, it was probably not until the imperial period that the novel became a genre at all; before then it was more a habitus, an intellectual space within which certain relationships (psychological, cultural, religious) could be ordered through the temporalised medium of prose narrative.

Flavius Josephus found himself at a crucial junction in the history of relations between the Greco-Roman and Jewish worlds, and not just for the obvious reasons connected to the sack of Jerusalem. Writing at a time when Greek 
identity was increasingly being defined through a literary heritage, Josephus both engaged with that heritage and challenged it, demonstrating that Jewish texts could compete for sophistication and subtlety with the most au courant Greek forms. This process was not, of course, new with Josephus himself - it began with the Septuagint, and was energised by figures like Artapanus and Philo-but Josephus certainly represents a milestone in terms of the range and ambition of Greek cultural forms used (I have focused solely on romantic topoi). It is arguably with Josephus that we see the strongest case that Javan is, in cultural terms as well as ethnic, indeed the grandson of Noah.

Corpus Christi College, Oxford

\section{NOTES}

1. The use of the modern term 'literature' in relation to the ancient world has been rightly problematised (S. Goldhill, 'Literary History without Literature: Reading Reading Practices in the Ancient World', SubStance 28 [1999], 57-89), but it would be misleading to deny that Greek identity was closely allied to the ideal of producing texts of high intrinsic and (hence) cultural value, an ideal that has itself been influential on modern ideas of literature. The association between Hellenism and 'literature' was felt strongly by non-Greek peoples: see e.g. the arguments of (among many others) D. Feeney, 'The Beginnings of a Literature in Latin', JRS 95 (2005), 226-40, at 230, that "for the Romans "literature" and "Greek literature" were co-extensive sets in the Venn diagram of the Mediterranean'. My own views on the question of 'Greek literature' can be found at T. Whitmarsh, Ancient Greek Literature (Cambridge 2004), passim, esp. 3-17. I am grateful to all the participants in and organisers of the Cambridge Josephus colloquium, and particularly to Honora Chapman for follow-up advice. Francesca Stavrakopoulou has been generous and patient towards a clumsy neophyte in matters Hebraic.

2. For the central role of pronoia in Josephus' works see $B J 3.28,5.60 ; A J 1.225,283 ; 3.19,23$; 4.47, 114-17; 10.277-80; Ap. 2.180; and further H.W. Attridge The Interpretation of Biblical History in the Antiquitates Judaicae of Flavius Josephus (Missoula 1976), 67-107; C. Daude, 'Flavius Josephe: prédiction et histoire', in É. Smadja and É. Geny (eds.), Pouvoir, divination, prédestination dans le monde antique (Paris 1999), 81-107. I have not seen A.A. Bailey, Josephus' Use of Heimarmene: An Interpretation of his Philosophy of Jewish History Related to the Destruction of Jerusalem (Diss. Brigham Young 1990). In general on the question of Hellenism see C. Schäublin, 'Josephus und die Griechen', Hermes 110 (1982), 316-41, who however rather simplifies the cultural politics by emphasising Josephus' dependence on (i.e. subordination to?) Greek models.

3. iớ or hov (gilliflower/violet): Nic. Georgica fr. 74.1-8 Gow = Ath. Deipn. 683a-b; cf. 681d; repeated at Eust. Commentarii ad Hom. Od. 1.201; possibly also behind Hecataeus fr. 1a 1F.37 FGrH. Eur. Ion: 'Ion' so named because he was met 'while going' (ióvt1), 831.

4. G.J. Wenham, Word Biblical Commentary, Genesis 1-15 (Waco 1987), 213-15.

5. Biblical translations come from the New Revised Standard Version.

6. Alashiya appears in Akkadian, Hittite and Ugaritic inscriptions, and may refer to the island or part of Cyprus: R. Pfeiffer, 'Hebrews and Greeks before Alexander', JBL 56 (1937), 91-101, at 9194; Wenham (n.4 above), 217f. On the evidence for Greek contact with the Syropalestinian world, see A.C. Hagedorn, "Who Would Invite a Stranger from Abroad?" The Presence of Greeks in Palestine in Old Testament Times', in R.P. Gordon and J.C. de Moor (eds.), The Old Testament in its World (Leiden 2005), 68-93.

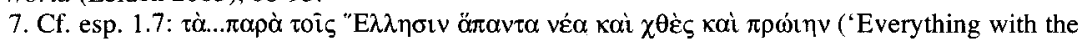
Greeks is new - either yesterday or the day before', reworking Pl. Tim. 22b-c).

8. I take the phrase 'outpasting' from D. Feeney, Caesar's Calendar: Ancient Time and the Beginnings of History (Berkeley \& London 2007), 29, who in turn takes it from E. Zerubavel, Time Maps: Collective Memory and the Social Shape of the Past (Chicago 2003), 105-09.

9. The 'house of Joseph': Josh. 17:17, Amos 5:6. Cf. also Ezek. 37:16-19. 


\section{TIM WHITMARSH}

10. G. von Rad, Wisdom in Israel, tr. J.D. Martin (London 1972), 46f., discusses the Joseph story in connection with 'narrative art' and 'mastery' (46).

11. C. Westermann, Genesis 37-50: A Commentary, tr. J.H. Scullion (Minneapolis 1986), 23.

12. Westermann (n.11 above), 252: 'a remarkably faint echo', with references; also J.L. Kugel, In Potiphar's House: The Interpretive Life of Biblical Texts (Cambridge MA 1990), 15-17.

13. A. Meinhold, 'Die Gattung der Josephsgeschichte und des Estherbuches: Diasporanovelle', I ZATW 87 (1975), 206-24; II ZATW 88 (1976), 72-93. The idea of a Josephan Novelle goes back to H. Gunkel, Genesis (Göttingen 1917), liii-lv. See also M. Braun, History and Romance in GraecoOriental Literature (Oxford 1938), 88f.; L. Wills, The Jewish Novel in the Ancient World (Ithaca 1995), 158-63.

14. M. Braun, Griechischer Roman und hellenistische Geschichtschreibung (Frankfurt am Main 1934); Braun (n.13 above).

15. Joseph is the best discussed of the Testaments of the Twelve Patriarchs (which survive in Greek, Armenian, Slavonic and Latin versions). For recent bibliography see R.A. Kugler, The Testaments of the Twelve Patriarchs (Sheffield 2001), 80-83.

16. Braun (n.13 above), 44-102. Braun's findings are qualified, but not rejected, by R.I. Pervo, 'The Testament of Joseph and Greek Romance', in G.W.E. Nickelsburg (ed.), Studies on the Testament of Joseph (Missoula 1975), 15-28. See also Wills (n.13 above), 163-70; L.H. Feldman, Josephus' Interpretation of the Bible (Berkeley \& Los Angeles 1998), 369-72.

17. Braun (n.13 above), 89f.; cf. also 94, where he speculates that there was a now-lost Joseph romance.

18. Some critics have seen the Greek novel as a creation of Chariton, in the mid-first century CE: see esp. E.L. Bowie, 'The Chronology of the Earlier Greek Novels since B.E. Perry: Revisions and Precisions', AncNarr 2 (2002), 47-63. The phrase 'historical novel' is not intended to denote a coherent genre, simply a diverse group of pre-romantic fictionalising texts focusing on a single historical figure. For a different interpretation of the phrase see T. Hägg, 'Callirhoe and Parthenope: The Beginnings of the Historical Novel', ClAnt 6 (1987), 184-204, repr. at T. Hägg, Parthenope: Studies in Ancient Greek Fiction (Copenhagen 2004), 73-98.

19. S. West, 'Joseph and Asenath: A Neglected Greek Romance', CQ 24 (1974), 70-81, at 80f.

20. R.S. Kraemer, When Aseneth Met Joseph: A Late Antique Tale of the Biblical Patriarch and his Egyptian Wife Reconsidered (Oxford 1998), 225-42, arguing for multiple narrative layers.

21. For further novelistic motifs see M. Philonenko, Joseph et Aseneth (Leiden 1968), 43-48; West (n.19 above); R.I. Pervo, 'Joseph and Aseneth and the Greek novel', Society of Biblical Literature 1976 Seminar Papers (1976), 171-81.

22. P.-D. Huet, Lettre-traité de l'origine des romans (Paris 1670; facsimile reproduction Stuttgart 1966), 11: 'l'invention [des Romans] eft deuë aux Orientaux: je veux dire aux Egyptiens, aux Arabes, aux Perfes, \& aux Syriens'. For more recent arguments for near-eastern influence see J.W.B. Barns, 'Egypt and the Greek Romance', Mitteilungen aus der Papyrussammlung der Nationalbibliothek in Wien 5 (1956), 29-34; G. Anderson, Ancient fiction: The Novel in the GraecoRoman World (London \& Sydney 1984); I. Rutherford, 'The Genealogy of the boukoloi: How Greek Literature Appropriated an Egyptian Narrative Motif', JHS 120 (2000), 106-21. I am not aware of any argument for the formative role of specifically Hebrew literature.

23. See in general H.W. Hollander, 'The Portrayal of Joseph in Hellenistic Jewish and Early Christian Literature', in M.E. Stone and T.A. Bergren (eds.), Biblical Figures Outside the Bible (Harrisburg PA 1998), 237-63, at 239-53.

24. On the portrait of Joseph in the Midrashim see Kugel (n.12 above), 28-124; I am persuaded by Dan Boyarin, however, that Kugel underplays the positive aspects of Joseph's Midrashic Nachleben (personal communication). The fragmentary papyrus History of Joseph (M. Black and A.-M. Denis [eds.], Pseudepigrapha Veteris Testamenti Graece Vol. 3 [Leiden 1970], 235f.; J.M. Charlesworth, The Old Testament Pseudepigrapha [London 1983-85], ii.466-75), usually thought of as Midrashic, lauds Joseph's political skills along the same lines as Philo's On Joseph (see below).

25. F. Stavrakopoulou, King Manasseh and Child Sacrifice: Biblical Distortions of Historical Realities (Berlin \& New York 2004), esp. 59-68, on the significance of Manasseh's name.

26. See in general M. Niehoff, The Figure of Joseph in Post-Biblical Jewish Literature (Leiden 1992); Hollander (n.23 above). Philo's different perspectives on Joseph are economically summarised at J.W. Earp, 'Indices to Volumes I-X', in F.H. Colson and J.W. Earp, Philo vol. $X$ (London \& Cambridge MA 1962), 351-57, esp. 351f. (the references are full and accurate, but not entirely systematically organised). 


\section{JOSEPHUS, JOSEPH AND THE GREEK NOVEL}

27. Cf. the claim that the name 'Joseph' derives from Hebrew words meaning 'addition of a lord' (28).

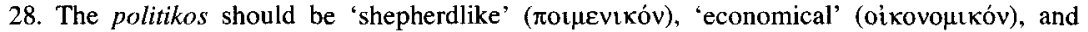

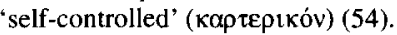

29. Niehoff (n.26 above), 27-32.

30. P. Ricoeur, Time and Narrative, tr. K. Maclaughlin and D. Pellauer (Chicago 1985), ii.101. I owe this reference to Larry Kim; see his excellent analysis of temporality in the Greco-Roman novel: L. Kim, 'Time', in T. Whitmarsh (ed.), The Cambridge Companion to the Greek and Roman Novel (Cambridge 2008), 145-61. Narratological analysis of Greek literary ideas of time can be found in I.J.F. de Jong and R. Nünlist (eds.), Time in Ancient Greek Literature (Leiden 2007), with extensive theoretical bibliography.

31. I.e. an element introduced at one point in the narrative in order to be picked up later.

32. He also uses narrative retardation to great effect. See Niehoff ( $\mathrm{n} .26$ above), 17-21; Wills (n.13 above), 159 and n.3.

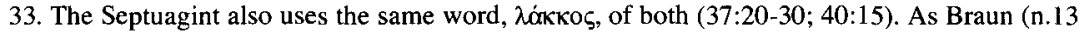
above, 79 n.1) notes: 'The word seems to have become typical of the Joseph story; for the translator of the T.T. [= Twelve Testaments] uses $\lambda \dot{\alpha}$ 'kкo $\varsigma$ only in connection with Joseph.'

34. bôr is used elsewhere of the underworld (e.g. Is. 14:19; Ps. 30:4).

35. Feldmann (n.16 above), 337.

36. Cf. especially Josephus' dream at Vit. 208-09. On Josephus' celebration of his own foresight see Daude (n.2 above); J.S. McLaren, 'Delving into the Dark Side: Josephus' Foresight as Hindsight', in Z. Rodgers (ed.), Making History: Josephus and Historical Method (Leiden 2007), 49-67.

37. Feldmann (n.16 above), 335.

38. On the theme of maturation in the Greek novel see esp. S. Lalanne, Une éducation grecque: rites de passage et construction des genres dans le roman grec ancien (Paris 2006).

39. On which see Kugel (n.12 above), 28-65.

40. E. Rohde, Der griechische Roman und seine Vorläufer ${ }^{3}$ (Leipzig 1914; repr. Hildesheim 1960), 155; S. Trenkner, The Greek Novella in the Classical Period (Cambridge 1958), 110.

41. E.g. Lys. 1.20; Lyc. 102-09; Plaut. Cist. 89-93 (perhaps $\sim$ Men. fr. 382 Körte); Braun (n.14 above), 49f. At Polyaen. 8.3.1 the rape of the Sabine women is said to occur at a

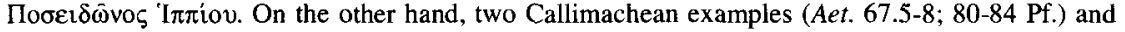
one of Parthenius' stories (32.2) display the novelised version of the topos.

42. For other 'novelised' examples see HId. 3.1-6 (a characteristically flamboyant extrava-

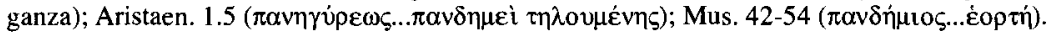

43. Braun (n.14 above), 55f., notes the similarities, but stops short of claiming a direct link. Current consensus puts Xenophon after Chariton, perhaps around $100 \mathrm{CE}$; this, however, is based on the highly questionable assumption that an apparent reference to the post of eirenarch (2.13.3; 3.9.5) must make the novel later than our earliest epigraphic attestation, in the time of Trajan (see in general on this issue Bowie [n.18 above], 56f.). It seems to me prima facie much more likely that Xenophon precedes the more sophisticated Chariton (so esp. J.N. O'Sullivan, Xenophon of Ephesus: His Compositional Technique and the Birth of the Novel [Berlin \& New York 1995], a valuable study the implications of which have not yet been fully digested).

44. Braun (n.14 above), esp. 37-51, 55f., 88-92, $101 \mathrm{f}, 111,114$.

45. See T. Hägg, Narrative Technique in Ancient Greek Romances: Studies of Chariton, Xenophon Ephesius, and Achilles Tatius (Stockholm 1971), 213-87; S. Bartsch, Decoding the Ancient Novel: The Reader and the Role of Description in Heliodorus and Achilles Tatius (Princeton 1989); and Morgan's contributions to de Jong and Nünlist (n.30 above), 479-87 ('Chariton'), 489-92 ('Xenophon of Ephesus'), 493-506 ('Achilles Tatius'), 507-22 ('Longus') and 523-43 ('Heliodorus').

46. The ideas in this paragraph are more fully elaborated in T. Whitmarsh, 'Desire and the End of the Greek Novel', in I. Nilsson (ed.), Loving Reading: Eros and the Poetics of Narrative (Copenhagen, forthcoming).

47. On Josephan providence see n.2 above.

48. On the Greek novel see esp. S. Montiglio, Wandering in Ancient Greek Culture (Chicago 2005), 221-61; on providence in Greek discussions of Roman rule, T. Whitmarsh, The Second Sophistic (Cambridge 2005), 69f. with further literature.

49. E.g. Pythagoras fr. 58 D6 DK; Eur. fr. 946 N2; Theocr. 24.69f.; also Hld. 2.24.7.

50. Rohde ( $\mathrm{n} .40$ above), first published in 1876 .

51. Huet (n.22 above). 